\title{
Predicting large wildfires across western North America by modeling seasonal variation in soil water balance
}

\author{
Richard H. Waring ${ }^{1} \cdot$ Nicholas C. Coops $^{2}$
}

Received: 29 June 2015 / Accepted: 19 November 2015 / Published online: 3 December 2015

C The Author(s) 2015. This article is published with open access at Springerlink.com

\begin{abstract}
A lengthening of the fire season, coupled with higher temperatures, increases the probability of fires throughout much of western North America. Although regional variation in the frequency of fires is well established, attempts to predict the occurrence of fire at a spatial resolution $<10 \mathrm{~km}^{2}$ have generally been unsuccessful. We hypothesized that predictions of fires might be improved if depletion of soil water reserves were coupled more directly to maximum leaf area index ( $\left.\mathrm{LAI}_{\max }\right)$ and stomatal behavior. In an earlier publication, we used $\mathrm{LAI}_{\max }$ and a process-based forest growth model to derive and map the maximum available soil water storage capacity $\left(\mathrm{ASW}_{\max }\right)$ of forested lands in western North America at $1 \mathrm{~km}$ resolution. To map large fires, we used data products acquired from NASA's Moderate Resolution Imaging Spectroradiometers (MODIS) over the period 2000-2009. To establish general relationships that incorporate the major biophysical processes that control evaporation and transpiration as well as the flammability of live and dead trees, we constructed a decision tree model (DT). We analyzed seasonal variation in the relative availability of soil water $(f A S W)$ for the years 2001, 2004, and 2007, representing respectively, low, moderate, and high rankings of areas burned. For these selected years, the DT predicted where forest fires $>1 \mathrm{~km}$ occurred and did not occur at $\sim 100,000$ randomly located pixels with an average accuracy of $69 \%$. Extended over the decade, the area predicted burnt varied by as much as $50 \%$. The DT identified four seasonal combinations, most of which included exhaustion of ASW during the summer as critical; two combinations involving antecedent conditions the previous spring or fall accounted for $86 \%$ of the predicted fires. The approach introduced in this paper can help identify forested areas where management efforts to reduce fire hazards might prove most beneficial.
\end{abstract}

Richard H. Waring

richard.waring@oregonstate.edu

1 College of Forestry, Oregon State University, Corvallis, OR, USA

2 Department of Forest Resource Management, University of British Columbia, 2424 Main Mall, Vancouver, Canada 


\section{Introduction}

Throughout the western United States and western Canada the area burnt by wildfires has varied annually over the last three decades by nearly 10-fold (Skinner et al. 1999; Littell et al. 2009). Although regions with Mediterranean climates, characterized by dry summers and warm winters, are more prone to wildfires than those receiving summer precipitation, the patterns are not easily predicted across 34 ecoregions that contain forests (Waring et al. 2011). There seems little disagreement, however, that since the 1980s, climatic warming has extended the areas prone to fires (Westerling et al. 2006) as mountain snow packs melt earlier and the growing season is extended to higher elevation forests (Hamlet et al. 2006).

Although fire histories differ significantly among regions in western North America, recent trends in area burned are generally upward, sometimes approaching or exceeding estimates of areas burnt since Europeans settled the continent (Swetnam and Betancourt 1998; Schoennagel et al. 2004; Balshi et al. 2007; Weisberg and Swanson 2003; Fry and Stephens 2006; Riley et al. 2013; Dennison et al. 2014). Higuera et al. (2015) showed "that models developed using fire-climate relationships from recent decades over predict areas burned when applied to earlier periods." They suggests that accumulation of fuels following a long periods of unusually low fire activity, combined with more effort to control wildfires, may have contributed to altered fire-climate relationships, a view supported by others (e.g., Marlon et al. 2012, North et al. (2015).

Littell et al. (2009) analyzed climatic controls on the area burnt since 1916, showing that different ecoregions in the western U.S. varied in their sensitivity to antecedent conditions. Westerling et al. (2002) developed a statistical method, using the Palmer Drought Severity Index (PDSI) to forecast the area burned in different forest provinces. They inferred a strong negative association with the availability of soil moisture immediately prior to the fire season in most heavily forested federal lands, while in more arid regions, the relationship was reversed, and applied up to a year earlier. A strong positive correlation between antecedent soil moisture and wildfires should be expected where the forest canopy is sparse and moist soils allow for the development of a lush understory. Such an understory, if composed of shallow-rooted grasses, forbs and shrubs, quickly dries during a dry summer and become flash fuel (Dimitrakopoulos and Bemmerzouk 2003). These high correlations between extreme weather conditions conducive to wildfires and area burned suggest that current management practices, when limited to small,isolated areas, will have little effect on the extent of wildfires as climatic conditions continue to warm (Hessburg et al. 2015). On the other hand, knowing more accurately where large fires are most likely to occur should provide policy makers and managers a rational for action to reduce the likelihood of ignition (Syphard and Keeley 2015) and damage to natural and human resources (San-Miguel-Ayanz et al. 2013).

Clearly, not all forests are equally prone to wildfire. The marine West Coast forest zone of Oregon, Washington, and northern California, which support the highest leaf area and produce the greatest accumulation of live and dead biomass (Sun et al. 2004). rarely burns (Long et al. 1998; Riley et al. 2013). The reason for the infrequency of fire in this zone is because trees normally have access to sufficient water through fog-drip, dew and moist soils so as not to become flammable (Hessburg et al. 2015) except when essentially all available water is depleted from the rooting zone (Breda et al. 2006). There is some difficulty referencing flammability to foliar moisture content ( $\%$ dry mass) because non-structural carbohydrates and fats accumulate in foliage during the growing season (Jolly et al. 2012). Severe drought, 
associated with depletion of all available water in the rooting zone, combined with high evaporative demand, can cause foliage moisture contents to drop below $100 \%$ - $120 \%$, which is considered an approximate threshold below which a crown fire can be sustained (Agee et al. 2002). With further drying, the water conducting pathway of stems, roots, and branches may cavitate (Breda et al. 2006). When this happens, all tree components, as well as understory vegetation, litter and coarse woody debris, become highly flamable (Chuvieco et al. 2004).

The extent that a regional-scale extreme drought affects trees depends on their rooting depth and their density of leaves. Peterman et al. (2013) demonstrated drought-associated outbreaks of bark beetle on pinyon pine were largely concentrated on shallow soils. Unfortunately, most large-scale soil maps are inprecise (Peterman et al. 2014). Coops et al. (2012) attempted to remedy this situation by inverting a process-based growth model, constrained by satellitederived estimates of maximum leaf area index $\left(\mathrm{LAI}_{\max }\right)$, to derive estimates of the available soil water storage capacity $\left(\mathrm{ASW}_{\max }\right)$ as well as soil fertility $\left(\mathrm{S}_{\mathrm{f}}\right)$ at a spatial resolution of $1 \mathrm{~km}$ across most of western North America. The estimates of $\mathrm{ASW}_{\max }$ are more accurate than those of $\mathrm{S}_{\mathrm{f}}$ because drought-adapted forests generally have $\mathrm{LAI}_{\max }$ values $<3.0$, whereas more fertile, less drought-prone forests often have $\mathrm{LAI}_{\max }>6.0$.

To estimate the state of plant dessication accurately requires refinements that are rarely included in even sophisticated hydrologic models (e.g., Elsner et al. 2010). For example, transpiration needs to be recognized as a non-linear function of $\mathrm{LAI}_{\max }$, which can vary interannually by $>50 \%$ (Breda et al. 2006). Below an $\mathrm{LAI}_{\max }$ of $\sim 5.0 \mathrm{~m}^{2} \mathrm{~m}^{-2}$ maximum transpiration rates are reduced linearly; whereas above that threshold, the rates plateau as progressively more leaf- shading restricts stomatal opening (Granier et al. 2000). Similarly, the depletion of available water in the rooting zone exerts non-linear constraints on stomatal conductance, and thus alters the time required to dissicate living vegetation (Sucoff 1972; Sun et al. 1995).

We hypothesize that models that include $\mathrm{LAI}_{\max }$ and assess the implications of seasonal variation in soil water balances should improve predictions of fire occurrences over those that lack these features. In this paper, we evaluate the extent that large forest fires since the turn of the 21 st Century can be predicted at a spatial resolution of $1 \mathrm{~km}$ based on simulated patterns of available soil moisture affected by changing climatic conditions. To accomplish this, we use the same process-based growth model, climatic data, and derived estimates of $\mathrm{ASW}_{\max }$ previously employed by Coops et al. (2012) for the period 2000-2009. MODIS Active fire "hotspot" (MCD14DL) data with a spatial resolution of $1 \mathrm{~km}$ served as our reference to the location and size of wildfires; this dataset compares well with $30 \mathrm{~m}$ Landsat fire mapping (Hantson et al. 2013) with methods available to improve resolution at daily time steps (Parks 2014).

\section{Methods}

In this section, we define the baseline against which modeled predictions of fire were compared, introduce the model used to make predictions of monthly depletions in available soil water and constraints on transpiration, and describe the construction of maps and statistical comparisons made to evaluate the relations between predicted and observed wildfires. Our analysis encompasses forested sites in 34 ecoregions distributed from $32.5^{\circ} \mathrm{S}$ to $60^{\circ} \mathrm{N}$ Latitude and from $110^{\circ} \mathrm{W}$ to $126^{\circ} \mathrm{W}$ Longitude. It excludes most of the Yukon Territory where peat and permafrost are more prevalent than in the rest of the study area, and thus corresponds with our 
previous analyses of species distribution and forest disturbance in response to recent climatic variation (Coops et al. 2011).

\subsection{Selection and processing of MODIS hotspot data}

We acquired MODIS-derived (MCD14DL) active fire "hotspot" $1 \mathrm{~km}$ maps from 2000 through 2009 from the United States Forest Service (USFS) at $1 \mathrm{~km}$ resolution from across western North America (http://activefiremaps. fs.fed.us/gisdata.php). The fire-detection algorithm relies on temperatures detected at two thermal infrared wavelength that can discriminate active fires as small as $100 \mathrm{~m}^{2}$ at $\sim 1000^{\circ} \mathrm{K}$ when viewed from nadir, and has a $50 \%$ chance of identifying large (1-2 $\mathrm{km}^{2}$ ) smoldering fires at $\sim 600^{\circ} \mathrm{K}$ (Giglio et al. 2003). MODIS imagery, which includes other spectral bands, is used to screen for false thermal signals and to mask for clouds at a spatial resolution of $250 \mathrm{~m}$ (Justice et al. 2002).

We selected fire event recorded for three years $(2001,2004,2007)$ because these years represent, respectively, low, moderate, and high rankings in area burned during the decade 2000-2009. To minimize registration errors, all isolated (hotspot) fires of $<100$ ha within a $3 \times 3 \mathrm{~km}$ area were excluded from the analysis. We further defined a set of random points within the study area for analysis that included only those masked as forests and not registered as burnt in the three selected reference years. In total, over the 3 years, 50,080 pixels were detected as active fires within forested pixels throughout the region. A commensurate number of randomly selected fire-free pixels were also selected over the three fire seasons.

\subsection{Climatic data}

Mean monthly climate spatial surfaces were generated using ClimateWNA (Wang et al. 2012). The program extracts and downscales PRISM (Daly et al. 2008) and ANUSPLIN (Hutchinson 2004 generated monthly data $(2.5 \times 2.5$ arcmin) to $1 \mathrm{~km}$ and calculates seasonal and annual climate variables for specific locations based on latitude, longitude and elevation. Elevation adjustments are achieved through a dynamic local regression function developed individually for each monthly climate variable in the baseline dataset. To provide the required elevation data for ClimateWNA at $1 \mathrm{~km}$, a $90 \mathrm{~m}$ Digital Elevation Model (DEM) was resampled from the Shuttle Radar Topography Mission (SRTM). Spatial layers and point -based climate estimation are available online at: http://cfcg.forestry. ubc.ca/projects/climatedata/climatebcwna/. Mean monthly daytime vapor pressure deficits (VPDs) were estimated by assuming that the water vapor concentrations present on the day would be equivalent to those held at the mean minimum temperature (Kimball et al. 1997). The maximum mean VPD was calculated each month as the difference between the saturated vapor pressure at the mean maximum and minimum temperatures. Mean daytime VPD was calculated at two thirds of the maximum value. The number of days per month with subfreezing temperatures $\left(\leq 2{ }^{\circ} \mathrm{C}\right)$ was estimated from empirical equations with mean minimum temperature. Subfreezing temperatures are important because they cause stomata to close, and to remain close for at least a day (Hadley 2000).

Monthly estimates of total incoming short-wave radiation were obtained by combining the synoptic and zonal variation captured by the North American Regional ReAnalysis (NARR). NARR is an improved version of the National Center for 
Environmental Prediction/National Center for Atmospheric Research (NCEP NCAR) Global reanalysis data may be downloaded from the www.cdc.noaa.gov. Briefly, the surface radiation balance (e.g., incoming and outgoing shortwave and longwave) is estimated using a precipitation assimilation procedure (Zhao et al. 1997) that adjusts ambient conditions to closely match precipitation measurements from a variety of sources. Down-scaling was accomplished making topographic adjustments based on an approached developed by $\mathrm{Fu}$ and Rich (2002) to produce $1 \mathrm{~km}$ radiation surfaces from the broader scale NARR layers.

\subsection{Process-based model to predict transpiration, evaporation, and soil water depletion}

There are a wide variety of physiologically-based process models, but only a few have been designed to scale projections of photosynthesis, structural growth and mortality across landscapes (see the review by Mäkelä et al. 2000). Among the most widely used is the 3-PG model (Landsberg and Waring 1997). The 3-PG model differs from others primarily in a number of simplifying assumptions: (1) that monthly mean climatic data are adequate to capture major trends in drought; (2) that autotrophic respiration $\left(\mathrm{R}_{\mathrm{a}}\right)$ and net primary production (NPP) are approximately equal fractions of gross photosynthesis (GPP); and (3) that the proportion of NPP allocated to roots increases from $25 \%$ to $60 \%$ as nutrients (particularly nitrogen) become progressively less available.

The model (edition 3PGpjs2.7) calculates gross photosynthesis, canopy evaporation and transpiration, growth allocation and litter production at monthly intervals $(\Delta t)$. It reduces potential photosynthesis and transpiration by imposing restrictions on stomatal conductance through modifiers, taking values between $0=$ complete restriction and $1.0=$ no restriction, that account for the effects of frost, high vapor pressure deficits and limitations in available soil water content. The soil water modifier $(f A S W)$ is determined as a non-linear function from the ratio of the amount of water available in the root zone of the trees $(A S W)$ to the maximum value $\left(A S W_{\max }\right) . A S W_{\max }$ is the available water holding capacity of the soil, which is the difference between the water content in the root zone at field capacity and at the wilting point. For any given month, ASW is calculated from:

$$
A S W(t+\Delta t)=A S W(t)+(P-E-T)
$$

where $A S W(t)$ is the value at the beginning of the month and $P, E$ and $T$ denote the monthly values of precipitation, evaporation and transpiration, respectively. The model includes a term to account for rainfall interception by the forest canopy; this water is assumed to be lost by evaporation, giving $E$. Transpiration is calculated from the Penman-Monteith equation, which incorporates a canopy conductance term derived from stomatal conductance and LAI. If the value of $A S W$ on the left-hand-side of Equation (1) exceeds $A S W_{\max }$, i.e., the whole root zone is at field capacity, the excess is assumed to be lost as runoff or drainage.

At monthly time steps, the model is unable to compute a snow water balance accurately, although one may assume that precipitation in months with average temperatures well below freezing is largely in the form of snow, but changes in albedo, incident radiation and other factors determine the accumulation and melting 
dates of snow (Coughlan and Running 1997; Elsner et al. 2010). At annual time steps, the model sums monthly changes in tree number, mean diameter, stand basal area, above-ground volume and biomass and updates the changes in LAI.

To account for seasonal adjustments in temperature optima (Hember et al. 2010) and to incorporate the large genetic variation among populations of Douglas-fir, we broadened the range for which photosynthesis could remain above $50 \%$ of maximum to lie between $0{ }^{\circ} \mathrm{C}$ and $35{ }^{\circ} \mathrm{C}$ by setting minimum, optimum and maximum temperatures at $-7{ }^{\circ} \mathrm{C}, 18{ }^{\circ} \mathrm{C}$ and $40{ }^{\circ} \mathrm{C}$, respectively. The photosynthetic response at temperatures below $-2{ }^{\circ} \mathrm{C}$ is truncated to zero because stomata are closed below this temperature threshold (Hadley 2000).

The fertility-dependent growth modifier in the 3-PG model is a function of the soil fertility rating, $S_{f}$, which ranges between zero, for the poorest soils, to unity for most fertile soils (Landsberg and Waring 1997). As previously mentioned, we generated estimates of $\mathrm{S}_{\mathrm{f}}$ and $A S W_{\max }$ at $1-\mathrm{km}$ resolution for all forested sites by inverting the 3-PG model to achieve close agreement between modeled $\mathrm{LAI}_{\max }$ and MODIS-derived observations over the range from 0.5 to $6.0 \mathrm{~m}^{2} \mathrm{~m}^{-2}$ (Coops et al. 2012). The model was parameterized for Douglas-fir with the same values used to derive estimates of soil properties (Waring and McDowell 2002; Coops et al. 2012).

\subsection{Comparison of model predictions with MODIS hotspot data}

The 3-PG model predictions of $f A S W$ were generated for each month for the years 2000 through 2009. The monthly values were averaged for the four seasons (winter: December-February; spring: March-May; summer: June-August, autumn: SeptemberNovember). We chose to apply a decision tree analysis to develop relationships between the seasonal $f A S W$ and the presence and absence of fire in 2001, 2004, and 2007. Decision tree models are increasingly selected for model development in ecological research because of their ability to deal with collinear datasets, to exclude insignificant variables, and to allow for asymmetrical distribution of samples (De'ath 2002, Schwalm et al. 2006; Melendez et al. 2006). They, like non-linear panel modelling and other recent statistical innovations, allow for links to be developed between environmental data and fire occurrence even with incomplete information and variable correlations (An et al. 2015).

The Decision Tree approach separates the dependent variables (seasonal $f A S W$ ) into a series of binary (yes/no) choices that identifies, by the topography in the decision tree, if pixels have been detected as a hot spot in the MCD14DL layer. Decision Tree Regression (DTREG) software (Sherrod 2010) was used to create a decision tree using 10 -fold cross validation technique where the data are separated randomly into 10 equally sized subsets and models developed on nine of the groups, and then tested against the remaining $10 \%$. This process of k-fold partitioning is then repeated with results merged to produce a final classification tree (Breiman et al. 1984). To assess accuracy once the model was created, a 'confusion matrix' was developed, which provides an indication of the positive and negative predictive power of the model as well as a number of other statistics (Fielding and Bell 1997, but see caveats in Lobo et al. 2008). Our analysis included an evaluation of the amount of variance accounted for in the model by each of the seasonal indices of $f(A S W)$. Once developed, the model was run with the derived seasonal indices of soil water depletion to predict annual fire 
occurrence layers for each year over the decade (starting with data from 1999). A total of 99,930 pixels were evaluated, half of which had recorded fires and half without.

\section{Results}

The decision tree model created four rules based on current and previous year's seasonal patterns in $f A S W$ to predict the location of active fire hotspots in the three years analyzed. Three of the rules, depicted in Fig. 1, accounted for $99 \%$ of the predicted fires. All recognize the importance of summer drought in the year of the fire as of paramount importance. The model defined a summer threshold of $f(A S W)$ at 0.12 of optimum, below which fires would have high probability.

In the first decision rule, the indicator of summer drought is coupled with moderate drought conditions in the spring of the previous year, and drought the current fall. The second rule, unlike the 1st, predicts that sites with moderate rather than severe summer drought in the current year would still be fire prone if fall and winter conditions the year before were droughty. The third rule mirrors the first with summer drought in the current year and drought conditions in the previous fall, but recognizes that a favorable water balance the previous winter could stimulate the production of flash fuel. The last rule describes a similar pattern to the first and third with drought in the current summer, but with favorable spring growing conditions the previous year more important. Overall, the decision tree model (applying all 4 rules) accounted

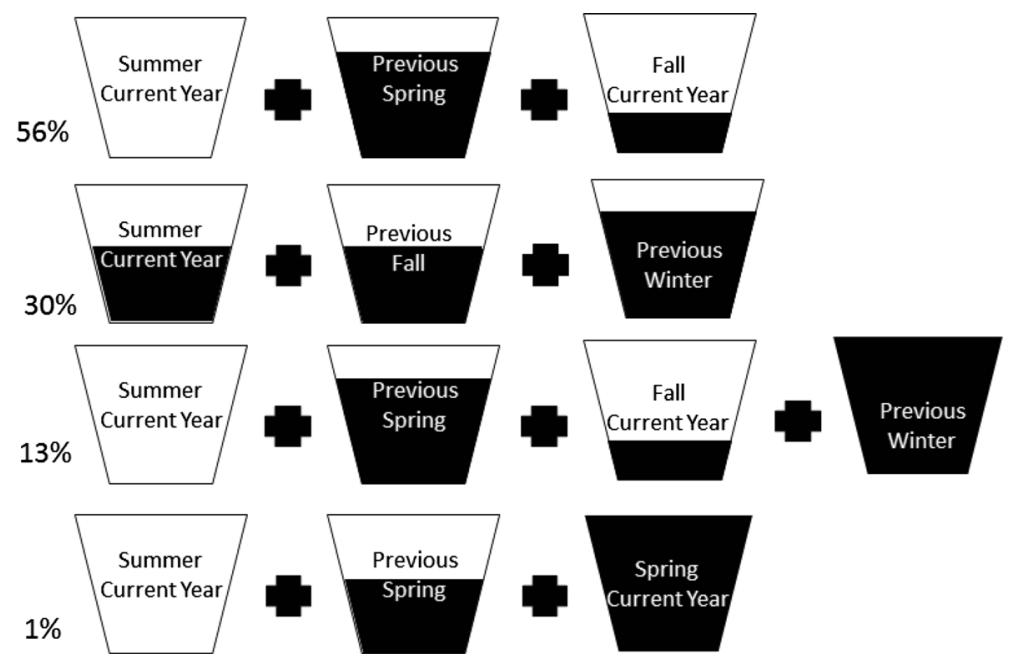

Fig. 1 Schematic diagram showing four separate decision tree rules that specify different seasonal combinations of the function available soil water content $(f \mathrm{ASW})$ where clear =completely depleted, all black = full capacity, others = black proportional to remaining capacity. The four rules were derived with seasonally averaged climatic data acquired across the study area in 2001, 2004 and 2007 and each of the respective previous years. The rules predict the occurrence of at least two, $1 \mathrm{~km}$ size fires within $3 \times 3 \mathrm{~km}$ sampled areas. The percentages that each of the 4 rules was utilized in predicting the presence or absence of wildfires across the study area are listed on the left side of the figure 


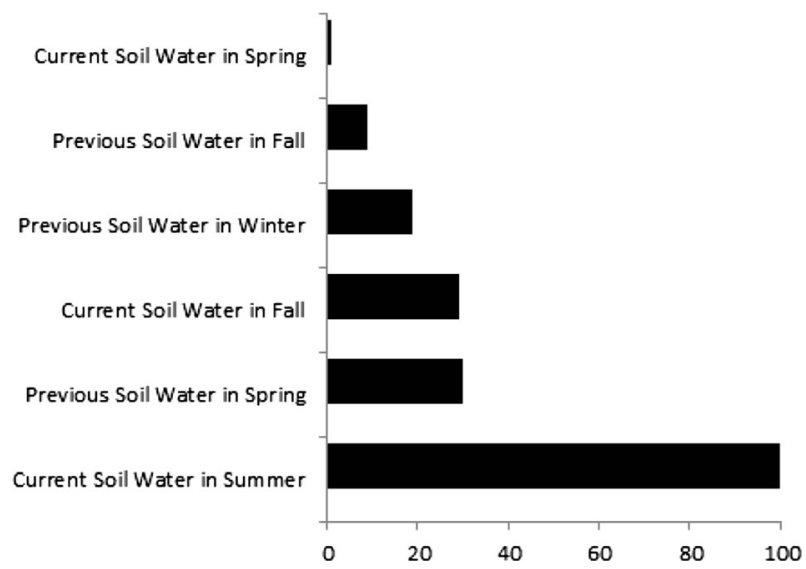

Fig. 2 The relative importance (x-axis) of different seasonal functions of available soil water $(f A S W)(\mathrm{y}-\mathrm{axis})$ varied in their contributions to the four rules used to predict MODIS Active hotspot occurrence of wildfires in 2001, 2004, and 2007

for $69 \%$ of the variance in fires recorded during the three selected calibration years, (70\% with fire absent, $68 \%$ when present).

The proportion of sites classified by each of the 4 rules varied from $1 \%$ to $56 \%$ with rules 1 and 2 contributing a total of $86 \%$ (Fig. 1). We note that unlike a linear regression model, a variable in a decision tree model can be important even if it never appears as a primary splitter at a node. The importance of a variable is assessed whether it serves in a primary and surrogate role based on the amount it improves, relative to the best identified variable, the overall model predictions.

Although a number of seasonal $f A S W$ of the current and previous year were used in the decision tree analysis, their relative importance differed; Fig. 2 provides a summary of how often seasonal $f A S W$ modifiers were utilized in our decision-tree model. The results confirm that the $f A S W$ modifier in summer of the analysis year was the most consistent and critical soil variable for predicting the occurrence of fire in that year. The next most important modifier was soil water status in the previous year's spring, explaining $30 \%$ of the variance comparable with $f A S W$ in the following summer. Similar in predictive power was $f A S W$ in the current fall. Lastly, the previous winter and the previous fall conditions contributed some explanatory power to the model.

Figure 3 provides a graphic display of the area predicted by the model (in orange) to be susceptible to fire along with actual locations in 2004 (black dots). The active fires in the forested areas of the study area were closely correlated spatially to high, dry plateaus in British Columbia, Idaho and Montana as well as to more coastal areas in northern California and throughout most of central California. In contrast, the coastal areas of British Columbia, and northern Washington and Oregon had very few active fires recorded in 2004. In addition, fires occurred frequently in the northern locations of the study area, in the southern Boreal Forest Region, in Alberta and Saskatchewan. In general, the predicted areas correspond fairly well to the active fire points. Areas where fires were observed in 2004, but the model 


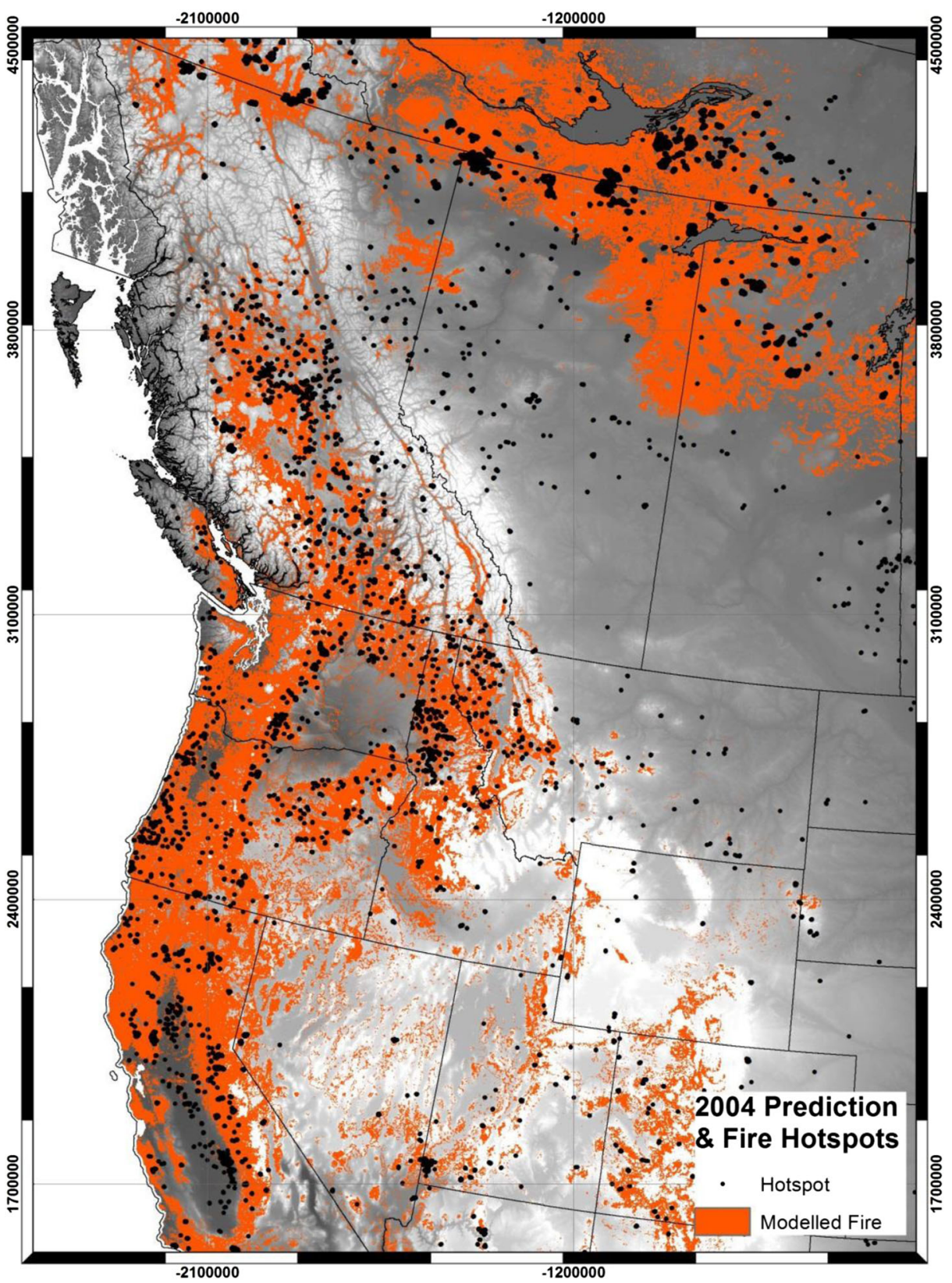

Fig. 3 Model predictions of wildfires for 2004 (orange) in forested portions of western North America and the locations of MODIS active fire hotspots (black dots) for the same period

predicted none, include central and eastern Montana, some places in Nevada and in the eastern foothills of the Rocky Mountains in Alberta.

Figure 4 provides a decadal summation of the model predictions, showing the likelihood of fire occurrence over the decade from 2000 to 2009 . The decadal map confirms the prevalence of fire in the forests of northern California, central 


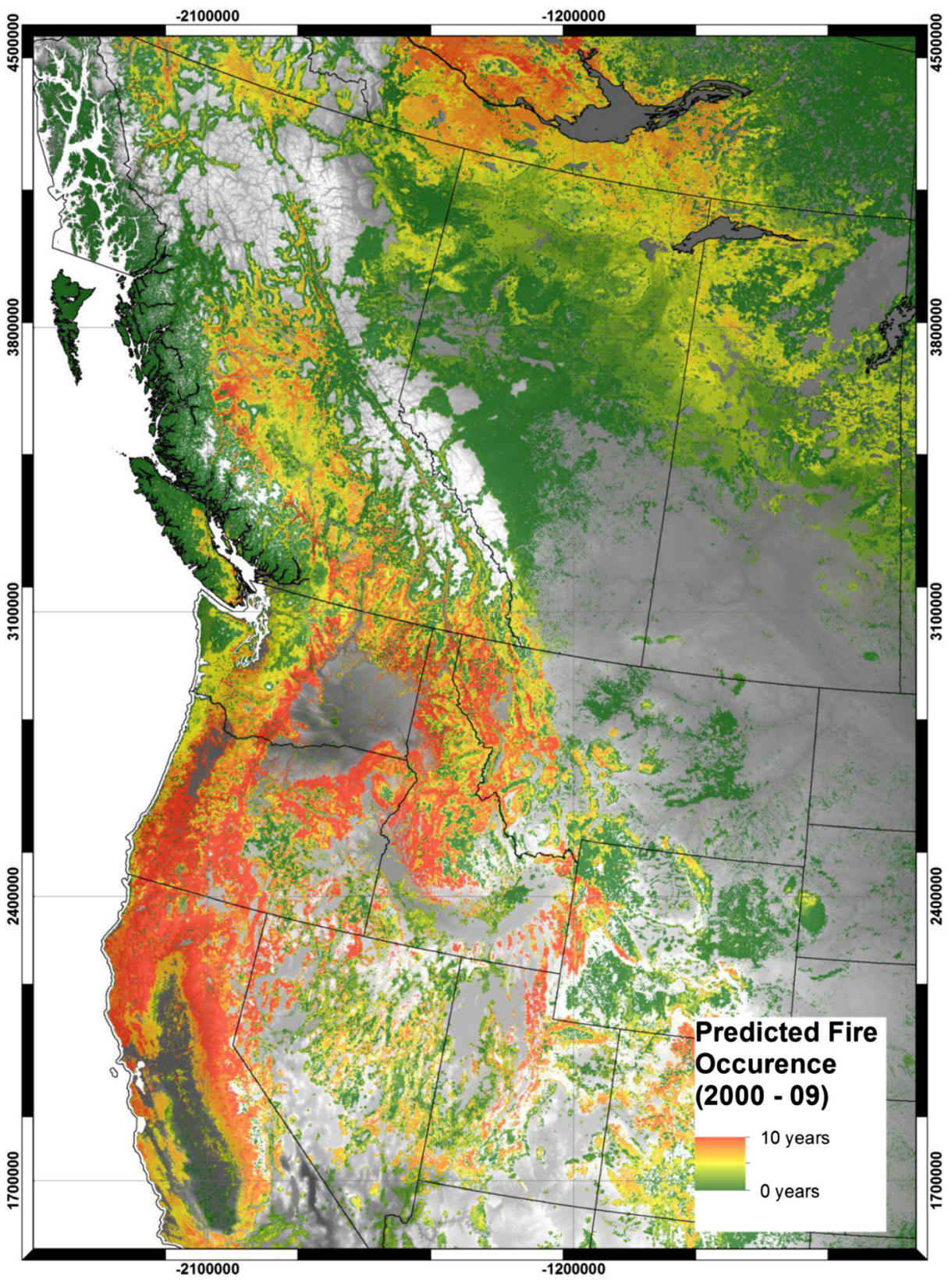

Fig. 4 Accumulated predicted fire occurrence for the decade 2000-2009 in forested $1 \mathrm{~km}$ pixels based on the decision tree models

Washington and Oregon, as well as the high plateau regions of British Columbia and the southern Boreal Region. The patterns differ somewhat from those indicated for a single year (Fig. 3) because outside of California, the location of the majority of predicted fires shifts considerably from year to year (maps not shown but are 


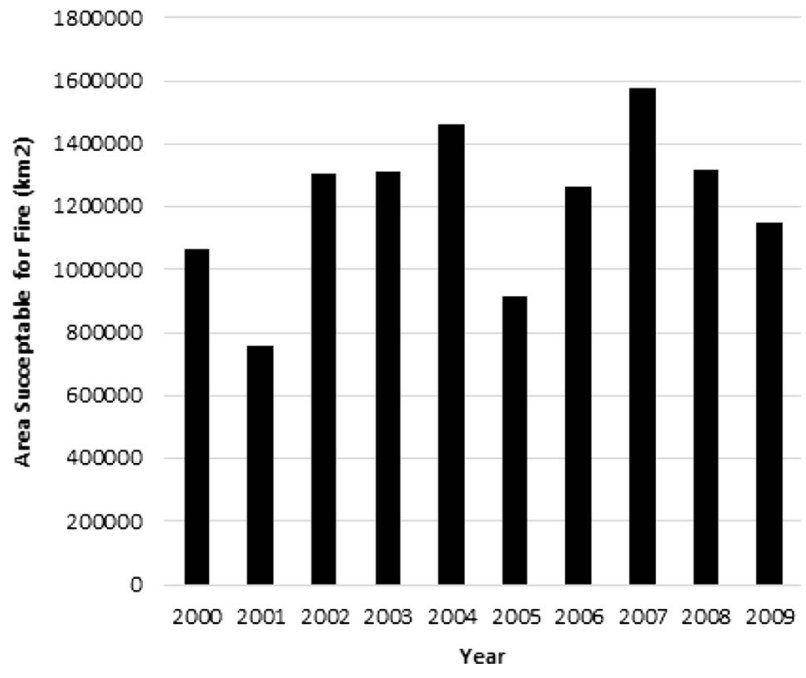

Fig. 5 Area of fires predicted between 2000 and 2009 based on the decision tree model

available online as 10 separate layers: http://databasin.org/datasets/78805401ae 8e467b942f05e985742a14

Lastly, the area predicted as most susceptible to fire across the study area from 2000 to 2009 is shown in Fig. 5 and highlights fire-prone years (2002, 2004 and 2007); 2007 was modeled at almost $30 \%$ above average and corresponded with one of the worst fire seasons on record in California. Conversely, some years were less prone to burn (2001, 2005 and 2009); 2001 was predicted to have $50 \%$ less area burnt than the average for the decade. The model predicted 2000, 2006 and 2009 as representing average fire conditions for the period.

\section{Discussion}

\subsection{Physiological insights}

Even at a spatial resolution of $1 \mathrm{~km}$, considerable variation occurs in topography, soils, and vegetation throughout the study area. Analyzing the occurrence of fire at $1 \mathrm{~km}$ subsumes much of this variation, increasing the probability that changes in weather conditions will account for much of the variation in predicting wildfires. It has been long recognized that $\mathrm{LAI}_{\max }$ normally reflects a balance with the availability of soil water during seasons with potential deficits (Grier and Running 1977). A disequilibrium is established when the hydrologic conditions are significantly altered. Even in very open pinyon pine and juniper woodland, an exceptional drought is required to weaken the pine to the extent that they are susceptible to bark beetle attack (Breshears et al. 2009). Process-based forest growth models, like 3-PG, establish upper limits of transpiration as a function of whole canopy stomatal conductance and evaporative demand. Once $\mathrm{LAI}_{\max }$ drops below $\sim 5.0$, the maximum rates of average daily transpiration fall from $\sim 3.0$ to $<0.5 \mathrm{~mm}$ day $^{-1}$ (Granier et al. 2000). It is important to recognize that dense forests exposed to high evaporative demand 
extract water much faster from the soil than more open stands; these differences compensates at times for variation in the $\mathrm{AWS}_{\max }$. But good estimates of $\mathrm{ASW}_{\max }$ are important. If all sites were assumed to have $200 \mathrm{~mm}$ at $\mathrm{AWS}_{\max }$, those with $\mathrm{LAI}_{\max }$ of 2.0 would require $>3$ months to draw down the supply to the extent that drought had any direct effect on stomata whereas those with an $\mathrm{LAI}_{\max }$ of 6.0 would reach the same point in about a month (Running and Coughlan 1988). By focusing on seasonal anomalies in $f(A S W)$ we were able to identify those conditions conducive to abnormally high production of ground fuel as well as those with highly flammable overstory vegetation.

\subsection{Improvements in modeling and data acquisition}

Using every year of hot spot data from 2000 to 2009 could result in issues with temporal autocorrelation if the possibility was high that large areas could burn more than once in the decade. By selecting 2001, 2004, and 2007 we tried to minimize this issue by allowing at least 3 years for fuels to accumulate at a site.

It would be possible to extend the analysis back to the early 70 s using Landsat imagery and to improve assessments of changes in forest structure henceforth by measuring the vertical distribution of LAI using airborne light detection and ranging (lidar) sensors (Lefsky et al. 2001; Bolton et al. 2015). More accurate estimates of $\mathrm{LAI}_{\max }$ would permit derivation of more precise estimates of biomass in dense forest than is now possible. To cover larger areas, radar and hyperspectral data can be combined to obtain estimates of standing biomass, which would provide a basis for assessing changes in the amount and vertical distribution of potential fuels (Treuhaft et al. 2003).

At a spatial resolution of $1 \mathrm{~km}$, model predictions of large wildfires begin to have policy implications (Kennedy and Johnson 2014; North et al. 2015). The possibility of prescribing fuel treatments in places where decision tree models or other types predict high probability of fire in the future would be a valuable application, one that would justify incorporating more detailed information on $\mathrm{ASW}_{\max }$ and $\mathrm{LAI}_{\max }$ in fireprediction models.

\subsection{Implications for fire ecology and management}

The approach introduced in this paper can identify areas where large fires may occur that could coalesce into mega fires (San-Miguel-Ayanz et al. 2013), and does so without recognizing regional or political boundaries. Almeida and Sands (2015) provide a new version of the 3-PG model with daily time-steps and other refinements that warrant testing during the active fire season. As presented, the approach reflects known fire histories quit well (69\% accuracy at $1 \mathrm{~km}$ resolution) and our understanding of how recurrent fires create a mosaic that define the distribution of forest types and their fuel characteristics. Understanding this pattern can inform forest restoration efforts so that they will be consistent with projected wildland fires.

Wildland fires can be expected to establish new landscape patterns over time, while correcting the "fire deficit" created following a century of fire exclusion (Marlon et al. 2012; North et al. 2015). The patterns are not expected to attain stability, however, because projected temperature increases, derived from 11 climate models, 
are expected to result in an increase in total cloud-to-ground lightning flashes of $12 \% \pm 5 \%$ per degree Celsius of global warming, equivalent to a $50 \%$ increase over the rest of this century for the contiguous United States (Romps et al. 2014). In some regions, such as southern California, most fires are human caused, either directly, or indirectly (Syphard and Keeley 2015). Regardless of the cause, fire is a catalyst for change in species distribution, migration, and extinction and ultimately may determine whether American forests remain a carbon sink in this century (Flannigan et al. 2000).

Acknowledgments We are indebted to Dr. Robbie Hember at the University of British Columbia for deriving estimates of solar radiation values for the entire study area. Also, we thank Professor John Baily, a fire ecologist at Oregon State University for his constructive comments on an earlier draft of the manuscript. This work was supported by NASA grant NNX11A029G to Waring from the program for Biodiversity and Ecological Forecasting and a Canadian NSERC Discovery grant RGPIN 311926 to Coops. Information on the 3-PG model is available at 3 pg.forestry.ubc.ca and code can be obtained upon request from the authors. Geographic data layers and model predictions are freely available at http://databasin.org/datasets/ $78805401 \mathrm{ae} 8 \mathrm{e} 467 \mathrm{~b} 942 \mathrm{f} 05 \mathrm{e} 985742 \mathrm{a} 14$.

Open Access This article is distributed under the terms of the Creative Commons Attribution 4.0 International License (http://creativecommons.org/licenses/by/4.0/), which permits unrestricted use, distribution, and reproduction in any medium, provided you give appropriate credit to the original author(s) and the source, provide a link to the Creative Commons license, and indicate if changes were made.

\section{References}

Agee JK, Wright CS, Williamson N, Huff MH (2002) Foliar moisture content of Pacific northwest vegetation and its relation to wildland fire behavior. For Ecol Manag 167:57-66

Almeida AC, Sands PJ (2015) Improving the ability of 3-PG to model the water balance of forest plantations in contrasting environments. Ecohydrol. doi:10.1002/eco.1661

An H, Gan J, Cho SJ (2015) Assessing climate change impacts on wildfire risk in the United States. Forests 6: 3197-3211. doi:10.3390/f6093197

Balshi MS, McGuire AD, Zhuang Q, Melillo J, Kicklighter DW, Kasischke E, Wirth C, Flannigan M, Harden J, Clein JS, Burnside TJ, McAllister J, Kurz WA, Apps M, Shvidenko A (2007) The role of historical fire disturbance in the carbon dynamics of the pan-boreal region: a process-based analysis. J. Geophy Res 112 : G02029. doi:10.1029/2006JG000380

Bolton DK, Coops NC, Wulder MA (2015) Characterizing residual structure and forest recovery following high severity fire in the western boreal of Canada using Landsat time-series and airborne Lidar data. Rem Sens Env 163:48-60

Breda N, Huc R, Granier A, Dreyer E (2006) Temperate forest trees and stands under severe drought: a review of ecophysiological responses, adaptation processes and long-term consequences. Annals For Sci 63:625-644

Breiman L, Friedman JH, Olshen RA, Stone CG (1984) Classification and regression trees. Wadsworth International Group, Belmont, California, USA

Breshears DD, Myers OB, Meyer CW, Barnes FJ, Zou CB, Allen CD, McDowell NG, Pockman WT (2009) Tree die-off response to global change-type drought: mortality insights from a decade of plant water potential measurements. Frontiers Ecol \& Envir 7:185-189

Chuvieco E, Aguado I, Dimitrakipoulos A (2004) Conversion of fuel moisture content values to ignition potential for integrated fire danger assessment. Can J For Res 34:2284-2293

Coops NC, Waring RH, Beier C, Roy-Jauvin R, Wang T (2011) Modeling the occurrence of fifteen coniferous tree species throughout the Pacific Northwest of North America using a hybrid approach of a generic process-based growth model and decision tree analysis. Appl Veg Sci 14:402-414

Coops NC, Waring RH, Hilker T (2012) Prediction of soil properties using a process-based forest growth model to match satellite-derived estimates of leaf area index. Remote Sens Envir 126:160-173

Coughlan JC, Running SW (1997) Regional ecosystem simulation: a general model simulating snow accumulation and melt in mountainous terrain. Landscape Ecol 12:119-136 
Daly C, Halbleib M, Smith JI, Gibson WP, Doggett MK, Taylor GH, Curtis J, Pasteris PP (2008) Physiographically sensitive mapping of climatological temperature and precipitation across the conterminous United States. Int J Climatology. doi:10.1002/joc.1688

De'ath G (2002) Multivariate regression trees: a new technique for modeling species-environment relationships. Ecol 83:1105-1117

Dennison PE, Brewer SC, Arnold JD, Moritz MA (2014) Large wildfire trends in the western United States, 1984-2011. Geophys Res Lett 41:2928-2933

Dimitrakopoulos AP, Bemmerzouk AM (2003) Predicting live herbaceous moisture content from a seasonal drought index. Int J Biometeorol 47:73-79

Elsner MM, Cuo L, Voisin N, Deems JS, Hamlet AF, Vano JA, Mickelson KEB, Lee S-Y, Lettenmaier DP (2010) Implications of 21 st century climate change for the hydrology of Washington state. Clim Chang 102:225-260

Fielding AH, Bell JF (1997) A review of methods for the assessment of prediction errors in conservation presence/absence models. Environ Conserv 24:38-49

Flannigan MD, Stocks BJ, Wotton BM (2000) Climate change and forest fires. Science of the Total Env. 262:221-229

Fry DL, Stephens SL (2006) Influence of humans and climate on the fire history of a ponderosa pine-mixed conifer forest in the southeastern Klamath mountains, California. For Ecol and Manag 223:428-438

Fu P, Rich PM (2002) A geometric solar radiation model with applications in agriculture and forestry. Comput Electron Agric 37:25-35

Giglio L, Descloitres J, Justice CO, Kaufman YJ (2003) An enhanced contextual fire detection algorithm for MODIS. Remote Sens Envir 87:273-282

Granier A, Loustau D, Bréda N (2000) A generic model of forest canopy conductance dependent on climate, soil water availability and leaf area index. Ann For Sci 57:755-765

Grier CG, Running SW (1977) Leaf area of mature northwestern coniferous forests: relations to site water balance. Ecol 58:893-899

Hadley J (2000) Effect of daily minimum temperature on photosynthesis in eastern hemlock (tsuga canadensis L.) in autumn and winter. Arct Antarct Alp Res 32:368-374

Hamlet AF, Mote PW, Clark MP, Lettenmaier DP (2006) Twentieth-century trends in runoff, evapotranspiration, and soil moisture in the western United States. J Clim 20:1468-1486

Hantson S, Padilla M, Corti D, Chuvieco E (2013) Strengths and weaknesses of MODIS hotspots to characterize global fire occurrence. Remote Sens Environ 131:152-159

Hember RA, Coops NC, Black TA, Guy RD (2010) Simulating gross primary production across a chronosequence of coastal douglas-fir forest stands with a production efficiency model. Agric For Meteorol 150:238-253

Hessburg PF, Churchill DJ, Larson AJ, Haugo RD, Miller C, Spies TA, North MP, Povak NA, Belote RT, Singleton PH, Gaines WL, Keane RE, Aplet GH, Stephens SL, Morgan P, Bisson PA, Rieman BE, Salter RB, Reeves GH (2015) Restoring fire-prone inland Pacific landscapes: seven core principles. Landscape Ecol. doi:10.1007/s10980-015-0218-0

Higuera PE, Abatzoglou JT, Littell JS, Morgan P (2015) The changing strength and nature of fire-climate relationships in the northern rocky mountains, U.S.A., 1902-2008. PLoS One 10:e0127563. doi:10.1371/ journal.pone. 0127563

Hutchinson MF (2004) Centre for Resource and Environmental Studies, Australian National University. November 23, 2005, http://cres.anu.edu.au/outputs/anusplin.php

Jolly WM, Parsons RA, Hadlow AM, Cohn GM, McAllister SS, Popp JB, Hubbard RM, Negron JF (2012) Relationships between moisture, chemistry, and ignition of pinus contorta during early stages of mountain pine beetle attack. For Ecol Manag 269:52-59

Justice CO, Giglio L, Korontzi S, Owens J, Morisette JT, Roy D, Descloitres J, Alleaume S, Petitcolin F, Kaufman Y (2002) The MODIS fire products. Remote Sens Envir 83:244-262

Kennedy MC, Johnson MC (2014) Fuel treatment prescriptions alter spatial patterns of fire severity around wildland-urban interface during the wallow fire, Arizona, USA. For Ecol Manag 318:122-132

Kimball J, Running S, Nemani R (1997) An improved method for estimating surface humidity from daily minimum temperature. Agric For Meteorol 85:87-98

Landsberg JJ, Waring RH (1997) A generalized model of forest productivity using simplified concepts of radiation-use efficiency, carbon balance and partitioning. For Ecol Manag 95:209-228

Lefsky MA, Cohen WB, Parker GG, Hrding J (2001) Lidar remote sensing for ecosystem studies. BioSci 512:19-30

Littell JS, McKenzie D, Peterson DL, Westerling AL (2009) Climate and wildfire area burned in western U.S. ecoprovinces, 1916-2003. 2009. Ecol Appl 19:1003-1021

Lobo JM, Valverde AJ, Real R (2008) AUC: a misleading measure of the performance of predictive distribution models. Global Ecol and Biogeog 17:145-151

Long CJ, Whitlock C, Bartlein PJ, Millspaugh SH (1998) A 9000-year fire history from the Oregon coast range, based on high-resolution charcoal study. Can J For Res 28:774-787 
Mäkelä A, Landsberg J, Ek A (2000) Process-based models for forest ecosystem management: current state of the art and challenges for practical implementation. Tree Physiol 20:289-298

Marlon JR, Bartlein PJ, Gavin DG, Long CJ, Anderson RS, Briles CE, Brown KJ, Colombaroli D, Hallett DJ, Power MJ, Scharf EA, Walsh K (2012) Long-term perspective on wildfires in the western USA. Proc Nat Acad Sci USA 109:E535-E543

Melendez KV, Jones DL, Feng AS (2006) Classification of communication signals of the little brown bat. J Acoust Soc Amer 120:1095-1102

North MP, Stephens SL, Collins BM, Agee JK, Aplet G, Franklin JF, Fulé PZ (2015) Reform forest fire management: agency incentives undermine policy effectiveness. Science 349:1280-1281

Parks SA (2014) Mapping day-of-burning with coarse-resolution satellite fire-detection data. Int J Wildland Fire 23:215-223

Peterman W, Waring RH, Seager T, Pollock WL (2013) Soil properties affect pinyon pine-juniper response to drought. Ecohydrology 6:455-463

Peterman W, Bachelet D, Ferschweiler K, Sheehan T (2014) Soil depth affects simulated carbon and water in the MC2 dynamic global vegetation model. Ecol Model 294:84-93

Riley KL, Abatozoglou JT, Crenfell IC, Klene AE, Heinsch FA (2013) The relationship of large fire occurrence with drought and fire danger indices in the western USA, 1984-2008: the role of temporal scale. Int J Wildland Fire. doi:10.1071/WF12149

Romps DM, Seeley JT, Vollaro D, Molinari J (2014) Projected increase in lightning strikes in the United States due to global warming. Science 346:851-854

Running SW, Coughlan JC (1988) A general model of forest ecosystem processes for regional applications I. Hydrologic balance, canopy gas exchange and primary production processes. Ecol Model 42:125-154

San-Miguel-Ayanz J, Moreno JM, Camia A (2013) Analysis of large fires in European Mediterranean landscapes: lessons learned and perspectives. For Ecol Mang 294:11-22

Schoennagel T, Veblen TT, Romme WH (2004) The interaction of fire, fuels, and climate across rocky mountain forests. BioSci 54:661-676

Schwalm CR, Black TA, Amiro BD, Arain MA, Barr AG, Bourque CP-A, Dunn AL, Flanagan LB, Giasson MA, Lafleur PM, Margolis HA, McCaughey JH, Orchansky AL, Wofsy SC (2006) Photosynthetic light use efficiency of three biomes across and east-west continental-scale transect in Canada. Agric For Meteor 140: 260-286

Sherrod PH (2010) DTREG manual. Online at http://www.dtreg.com/DTREG.pdf (6 Oct 2015)

Skinner WR, Stocks BJ, Martell DL, Bonsal B, Shabbar A (1999) The association between circulation anomalies in the mid-troosphere and area burned by wild fire in Canada. Theor Applied Climatol 63:89-105

Sucoff E (1972) Water potential in red pine: soil moisture, evapotranspiration, crown position. Ecol 52:681-686

Sun OJ, Sweet GB, Whitehead D, Buchan GD (1995) Physiological responses to water stress and waterlogging in nothofagus species. Tree Physiol 15:629-638

Sun OJ, Campbell J, Law BE, Wolf V (2004) Dynamics of carbon stocks in soils and detritus across chronosequences of different forest types in the Pacific northwest, USA. Glob Chang Biol 10:1470-1481

Swetnam TW, Betancourt JL (1998) Mesoscale disturbance and ecological response to decadel climatic variability in the American southwest. J Clim 11:318-3147

Syphard AD, Keeley JE (2015) Location, timing and extent of wildfire vary by cause of ignition. Int J Wildland Fire 24:37-47

Treuhalf RN, Asner GP, Law BE (2003) Structure-based forest biomass from fusion of radar and hyperspectral observations. Geophy Res Letters 30:1472. doi:10.1029/2002GL016857

Wang T, Hamann A, Spittlehouse DL, Murdock TQ (2012) ClimateWNA - high-resolution spatial climate data for western North America. J. Appl. Meteor. Climatol. 51:16-29. doi:10.1175/JAMC-D-11-043.1

Waring RH, McDowell N (2002) Use of a physiological process model with forestry yield tables to set limits on annual carbon balances. Tree Physiol 22:179-188

Waring RH, Coops NC, Running SW (2011) Predicting satellite-derived patterns of large-scale disturbances in forests of the Pacific Northwest Region in response to recent climatic variation. Remote Sens Environ 115: 3554-3566

Weisberg PJ, Swanson FJ (2003) Regional synchroneity in fire regimes of western Oregon and Washington, USA. For Ecol Manag 172:17-28

Westerling AL, Gershunov A, Cayan DR, Barnett TP (2002) Long lead statistical forecasts of area burned in western U.S. wildfires by ecosystem province. Int J Wildland Fires 11:257-266

Westerling AL, Hidalgo HG, Cayan DR, Swetnam TW (2006) Warming and earlier spring increase western U.S. forest wildfire activity. Sci 313:940-943

Zhao Q, Black TL, Baldwin ME (1997) Implementation of the cloud prediction scheme in the eta model at NCEP. Weather Forecast 12:697-712 